\title{
Effects of senktide, a neurokinin 3 receptor agonist, on luteinizing hormone secretion and follicular development in anestrous Shiba goats: a pilot study
}

\author{
Natsumi Endo and Tomomi Tanaka*
}

\begin{abstract}
Background: Recent studies suggest that neurokinin B and its receptor, neurokinin 3 receptor, have an essential role in the regulation of gonadotropin-releasing hormone and luteinizing hormone $(\mathrm{LH})$ release in several mammalian species. As the first trial, this pilot study reports the effect of intravenous treatment with senktide, a selective agonist of neurokinin 3 receptor, on LH secretion, follicular development in female goats that were clinically diagnosed with anestrus.

Findings: Anestrous goats were intravenously administered $200 \mathrm{nmol}$ senktide at 4-h intervals for $24 \mathrm{~h}$. Most of them examined (5/6 cases) showed a pulsatile increase in LH secretion after each injection of senktide, whereas the remaining one case showed a surge-like increase of LH secretion. Ovulation was confirmed in 5/6 cases at the range of 48-96 $\mathrm{h}$ after the beginning of treatment.

Conclusions: This pilot study demonstrated that intravenous treatment with senktide has therapeutic action in goats with anestrus by inducing LH release, which could promote follicular development and ovulation.
\end{abstract}

Keywords: Anestrus, Goats, Senktide, LH, Ovulation

\section{Findings}

\section{Introduction}

Neurokinin B (NKB) is a member of the tachykinin family of peptides. Recent studies have revealed that hypothalamic signaling of NKB and its receptor, neurokinin 3 receptor (NK3R), has an important role in the regulation of gonadotropin-releasing hormone $(\mathrm{GnRH})$ neurosecretion in mammalian species [1]. Loss-of-function mutations of Tac3 and Tacr3, which encode NKB and NK3R, respectively, have been identified in patients with hypogonadotropic hypogonadism [2]. Subsequently, research using animal models found that exogenous administration of NKB stimulates neural oscillation governing pulsatile GnRH [3] and luteinizing hormone (LH) secretion [4,5]. NKB has affinity for other tachykinin receptors, even though marginal, which might compromise the interpretation of the

\footnotetext{
* Correspondence: tomomit@cc.tuat.ac.jp

Laboratory of Veterinary Reproduction, Tokyo University of Agriculture and Technology, 3-5-8 Saiwai-cho, Fuchu-city, Tokyo 183-8509, Japan
}

role of $\mathrm{NKB} / \mathrm{NK} 3 \mathrm{R}$ system in reproductive control [6]. To overcome this problem, senktide was developed as a highly selective and potent agonist of NK3R [7], and currently available only for experimental use. Along with investigating the physiological role of NKB/NK3R system in various stages of the reproductive process, attention is now focused on the therapeutic use of NK3R agonists, e.g. senktide, to accelerate or improve gonadal activity in humans as well as domestic animals [8].

Anestrus is a major component of postpartum infertility in domestic animals including dairy cows [9], which extends calving interval and leads great economic loss for farmers. Particularly in high-yielding dairy cows, occurrence of anestrus is often associated with nutritional deficiency in early lactation period. The condition of anestrus is characterized by the lack of ovarian cycles or gonadal activity with repeated turnover of follicles without ovulation. The existing follicles are incapable of producing sufficient estradiol-17 $\beta\left(\mathrm{E}_{2}\right)$ to induce ovulation, owing to the 
decreased secretion of GnRH and LH. Taking the endocrine background of anestrus into consideration, anestrous animals are relevant subjects for investigating the therapeutic action of NKB on ovarian dysfunction through the stimulation of $\mathrm{GnRH} / \mathrm{LH}$ secretion.

Shiba goats are non-seasonal breeders under natural daylight conditions in Japan, and are used as experimental and clinical models for the investigation of reproductive functions in domestic ruminants. Anestrus is also observed in this species, although the incidence is very low under normal management conditions. In this pilot study, we examined the effect of intravenous treatment with senktide on LH secretion and follicular development in anestrous female goats.

\section{Methods}

The study protocol was approved by the University Committee for Use and Care of Animals at Tokyo University of Agriculture and Technology (\#22-67). Five Shiba goats $(2.4 \pm 0.5$ years of age; $21.8 \pm 3.6 \mathrm{~kg}$ of body weight) that were clinically diagnosed with anestrus were subjected to the study. The goats and other herd-mates were maintained in an outdoor paddock and fed a maintenance diet based on alfalfa hay cubes twice daily, under group feeding conditions. The five goats had no estrus signs more than 30 days after the last appearance of estrus. After the expected day of estrus (20 or 21 days after ovulation), no functional corpus lutea and only antral follicles were detected by ovarian ultrasonography (7.5 MHz linear probe, HLS-375 M, Honda Electronics Co., Ltd., Aichi, Japan) and the progesterone concentration in plasma was lower than $1 \mathrm{ng} / \mathrm{ml}$. They received senktide on $48.2 \pm 16.8$ days after the last appearance of estrus.

On the day of the experiment, a catheter was inserted into the jugular vein. The goats were treated seven times with $200 \mathrm{nmol}$ senktide in $5 \mathrm{ml}$ of saline containing $0.25 \%$ dimethyl sulfoxide at 4 -h intervals, beginning at $1100 \mathrm{~h}$ (designated as $0 \mathrm{~h}$ ). The senktide solution was injected slowly over 5 minutes via the jugular catheter. The dose of senktide was determined according to a previous study [10] to induce pulsatile LH secretion in ovariectomized Shiba goats. Blood samples $(1.5 \mathrm{ml})$ were collected in heparinized tubes through the catheter at 10-min intervals from -2 to $4 \mathrm{~h}$, at 4-h intervals from 4 to $24 \mathrm{~h}$, at 6-h intervals from 24 to $48 \mathrm{~h}$ after the beginning of treatment, and thereafter at 24-h intervals up to $120 \mathrm{~h}$. Plasma was separated and assayed for LH, $\mathrm{E}_{2}$ and progesterone [11]. Ovarian ultrasonography was performed 2 days before the treatment, just before the treatment (between 0700 and $0800 \mathrm{~h}$ on the experiment day) and then daily until 5 days after treatment. All follicles and corpus lutea that were larger than $2 \mathrm{~mm}$ in diameter were recorded. All measured values are presented as means \pm SD. Differences between means were evaluated by analysis of variance followed by Dunnett's multiple comparison test or paired $t$-test. Differences with $\mathrm{P}<0.05$ were considered to be significant.

\section{Results}

Almost all cases (5/6, except for no.9) showed a pulsatile increase in LH concentration in response to each senktide treatment; the LH concentration increased rapidly and reached a peak at 10-20 min after each injection. In these five goats, LH concentrations at 10-20 min after the first injection and at $10-30 \mathrm{~min}$ after the second injection were significantly higher $(P<0.05)$ than the pretreatment level (Figure 1). As for $\mathrm{E}_{2}$, the mean concentration during the pre-treatment $2 \mathrm{~h}$ were $5.9 \pm$ $0.9 \mathrm{pg} / \mathrm{ml}$. The $\mathrm{E}_{2}$ concentrations fluctuated and no significant change was observed in the hourly profiles for $6 \mathrm{~h}$ after the senktide treatment.

Profiles of LH and $E_{2}$, occurrence of estrus and ovulation in all cases are shown in Figure 2. Estrus and ovulation were observed $2 / 6$ and $5 / 6$ cases, respectively. In the four of five cases that showed a pulsatile increase of $\mathrm{LH}$ release, ovulation occurred in response to senktide treatment at 72 (no.17) or $96 \mathrm{~h}$ (no.12-2, no.13 and no.15) after the beginning of treatment. Two cases (no.13 and no.15) showed standing estrus one to two days before the day of ovulation. $\mathrm{E}_{2}$ level showed a gradual increase through the 24-h repetitive injections. The peak of $E_{2}$ concentration, which was detected at 20-48 $\mathrm{h}$ after the beginning of treatment, was preceded or approximately coincided with the peak of LH.

Only one case (no.12-1) failed to ovulate, although a pulsatile increase in LH concentration was clearly observed in response to each injection of senktide. The $E_{2}$ concentration was higher than $5 \mathrm{pg} / \mathrm{ml}$ around the time of first injection. However, it decreased to the basal level by $6 \mathrm{~h}$ after the beginning of treatment and was maintained lower than $5 \mathrm{pg} / \mathrm{ml}$ throughout the experiment.

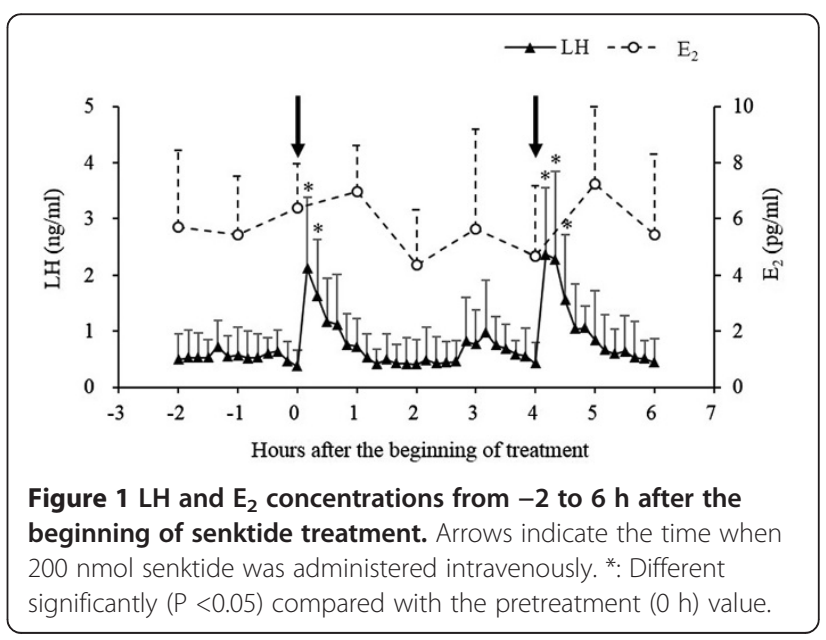




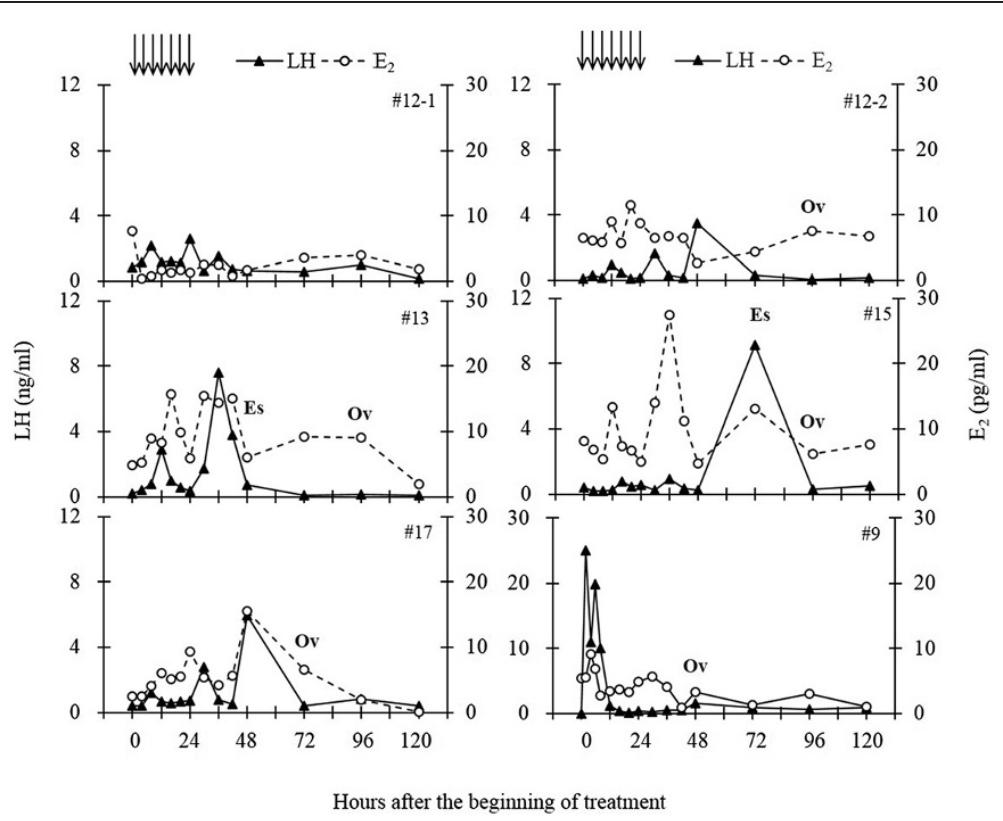

Figure 2 Profiles of $\mathbf{L H}$ and $E_{2}$, occurrence of estrus and ovulation in all six goats examined. Plasma $\mathrm{LH}$ and $\mathrm{E}_{2}$ concentrations in the samples collected every $4 \mathrm{~h}$ from 0 to $24 \mathrm{~h}$, every $6 \mathrm{~h}$ from 24 to $48 \mathrm{~h}$, and then every $24 \mathrm{~h}$ until $120 \mathrm{~h}$. Arrows indicate the time when $200 \mathrm{nmol}$ senktide was administered intravenously. Es: Estrus behavior was detected by visual observation. Ov: Ovulation was confirmed by ovarian ultrasonography.

Goat no.9 showed a different LH response from the other five goats. Mean concentrations of LH and $\mathrm{E}_{2}$ during the pre-treatment $2 \mathrm{~h}$ in this goat was $4.0 \pm 2.5 \mathrm{ng} / \mathrm{ml}$ and $8.1 \pm 4.7 \mathrm{pg} / \mathrm{ml}$, respectively. A surge-like increase in LH concentration was observed, with a peak of $56.1 \mathrm{ng} / \mathrm{ml}$ at $3 \mathrm{~h}$ after the first injection. The $\mathrm{E}_{2}$ concentration showed a concomitant increase with the increase of $\mathrm{LH}$, followed by a gradual decrease by the time of ovulation (at $48 \mathrm{~h}$ after the beginning of treatment).

Goats that ovulated upon the senktide treatment had 2-4 follicles with a diameter larger than $3 \mathrm{~mm}$ (mean, $4.0 \pm 0.6 \mathrm{~mm}$ ) on the day of treatment. Finally, $1-4 \mathrm{ovu}-$ latory follicles per goat grew after the treatment, and the mean maximal diameter of them was $4.8 \pm 0.6 \mathrm{~mm}$. The goat that failed to ovulate (no.12-2) had only one follicle with a smaller diameter of $2.7 \mathrm{~mm}$ on the day of treatment, although three additional small follicles were detected $24 \mathrm{~h}$ later.

Additional monitoring of ovarian dynamics and blood progesterone concentrations in the ovulated five goats indicated that premature luteal regression occurred (data not shown) and estrus was observed at 5-18 days after the senktide-induced ovulation.

\section{Discussion}

The present study showed the stimulatory action of NKB on the LH secretion in almost all goats with anestrous symptom, in which there was a pulsatile increase in LH concentration in response to each senktide treatment. Recently, it has been revealed that a specific subset of neurons in the arcuate nucleus (ARC) in the hypothalamus, colocalized three neuropeptides, kisspeptin, NKB and dynorphin [12,13], and is a likely candidate for the intrinsic GnRH pulse generator. Accumulating evidence suggests that the action of NKB or its analog occurs within the ARC through regulation of the release of kisspeptin [3,4]. An in vitro study using cell-attached recording method showed that both NKB and senktide have a potent stimulatory action on the firing of kisspeptin neurons derived from the ARC region of the mouse hypothalamus [14]. In ovariectomized goats, $\mathrm{GnRH}$ pulse generator activity at the ARC kisspeptin neurons, which was monitored by recording the multiple-unit activity in the hypothalamus, was stimulated after the intravenous injection of senktide [10]. It is suggested that small-amplitude release of LH (pulsatile LH secretion) is induced by the stimulatory action of NKB on the hypothalamic $\mathrm{GnRH}$ pulse generating system.

The present study is the first trial to evaluate the use of NKB for the treatment of anestrus in goats. The obtained findings are limited because there was no untreated control group. In addition, the exact reasons for anestrus remain unclear, but it is likely that insufficient nutrition intake or other related factors such as stress might be attributed to the incidence of anestrus, as has been experimentally demonstrated in feed-restricted animals $[15,16]$. Consequently, most cases showed a therapeutic outcome; there was a gradual increase in $E_{2}$ secretion followed by ovulation after the repetitive injections of senktide, at 4-h intervals for $24 \mathrm{~h}$. However, the treatment was insufficient 
for one goat (no.12) to stimulate follicular development, in spite of the increased LH stimulation caused by senktide treatment. One possible explanation for this is that the failure of follicular development and/or ovulation might be associated with the status of ovarian follicles during senktide treatment. According to ultrasonographic observation of ovaries during the estrous cycle in this species [17], ovulatory follicles appear from 5 days before ovulation and then grow to about 5 to $6 \mathrm{~mm}$ in diameter in parallel with the increase in the plasma $E_{2}$ concentration. In addition to the fact that the anovulated goat (no.12) had only one follicle sized $2.7 \mathrm{~mm}$ in diameter on the day of treatment, the constantly low level of $\mathrm{E}_{2}(<5 \mathrm{pg} / \mathrm{ml})$ also indicates the absence of steroidogenically active follicle(s) that can respond to LH stimulation. For optimal treatment of inactive ovary, the timing, duration and route of treatment seem to require adaptation according to the follicular and endocrine conditions.

In one goat (no.9), a prominent increase in LH concentration close to those observed during the preovulatory LH surge was observed following the first injection of senktide. A similar observation was reported from a study by Billings et al. [5], in which a surge-like increase in $\mathrm{LH}$ occurred after the treatment of senktide into the third ventricle in ewes during the follicular phase but not during the luteal phase. Although there may be limits to this pilot study as it is based one case, it seems likely that intravenous injection of senktide in a steroid milieu similar to that present during the follicular phase of the cycle can generate a preovulatory $\mathrm{GnRH} / \mathrm{LH}$ surge, as a trigger of ovulation.

In conclusion, the present pilot study showed that intravenous treatment with senktide can stimulate $\mathrm{LH}$ secretion in anestrous goats, suggesting the potential value of NKB application in the treatment of reproductive disorders. The increased release of LH resulted in ovulation in most cases, except for one goat. This different outcome might be associated with the developmental and steroidogenic status of ovarian follicles during senktide treatment.

\section{Abbreviations \\ $\mathrm{E}_{2}$ : Estradiol-17ß; GnRH: Gonadotropin-releasing hormone; LH: Luteinizing hormone; NKB: Neurokinin B; NK3R: Neurokinin 3 receptor.}

\section{Competing interests}

The authors declare that they have no competing interests.

\section{Authors' contributions}

NE designed and carried out the study, analyzed and interpreted the data, and drafted the manuscript. TT participated in the experimental design, interpretation of the data, and criticizing the manuscript. Both authors read and approved the final manuscript.

\section{Acknowledgements}

We thank Dr. Y. Mori, The University of Tokyo, for providing anti-ovine LH serum (YM \#18), Dr. A. F. Parlow and the National Hormone \& Peptide Program for providing reagents used in the LH radioimmunoassay, and
Dr. S. Oishi, Kyoto University, for providing senktide. We also thank Dr. H. Okamura (National Institute of Agrobiological Sciences), Dr. S. Ohkura (Nagoya University) and Dr. H. Kamomae (Tokyo University of Agriculture and Technology) for technical advice and productive discussions. This study was supported by a grant from the Ministry of Agriculture, Forestry and Fisheries of Japan (Research Program on Development of Innovative Technology for Animal Reproduction).

Received: 4 January 2014 Accepted: 24 October 2014

Published: 3 November 2014

\section{References}

1. Rance NE, Krajewski SJ, Smith MA, Cholanian M, Dacks PA: Neurokinin B and the hypothalamic regulation of reproduction. Brain Res 2010, 1364:116-128.

2. Topaloglu AK, Reimann F, Guclu M, Yalin AS, Kotan LD, Porter KM, Serin A, Mungan NO, Cook JR, Ozbek MN, Imamoglu S, Akalin NS, Yuksel B, O'Rahilly S, Semple RK: TAC3 and TACR3 mutations in familial hypogonadotropic hypogonadism reveal a key role for Neurokinin B in the central control of reproduction. Nat Genet 2009, 41:354-358.

3. Wakabayashi Y, Nakada T, Murata K, Ohkura S, Mogi K, Navarro VM, Clifton DK, Mori Y, Tsukamura H, Maeda K, Steiner RA, Okamura H: Neurokinin $B$ and dynorphin $A$ in kisspeptin neurons of the arcuate nucleus participate in generation of periodic oscillation of neural activity driving pulsatile gonadotropin-releasing hormone secretion in the goat. J Neurosci 2010, 30:3124-3132.

4. Ramaswamy S, Seminara SB, Ali B, Ciofi P, Amin NA, Plant TM: Neurokinin B stimulates $\mathrm{GnRH}$ release in the male monkey (Macaca mulatta) and is colocalized with kisspeptin in the arcuate nucleus. Endocrinology 2010, 151:4494-4503.

5. Billings HJ, Connors JM, Altman SN, Hileman SM, Holaskova I, Lehman MN, McManus CJ, Nestor CC, Jacobs BH, Goodman RL: Neurokinin B acts via the neurokinin-3 receptor in the retrochiasmatic area to stimulate luteinizing hormone secretion in sheep. Endocrinology 2010, 151:3836-3846.

6. Navarro VM: Interactions between kisspeptins and neurokinin B. Adv Exp Med Biol 2013, 784:325-347.

7. Wormser U, Laufer R, Hart Y, Chorev M, Gilon C, Selinger Z: Highly selective agonists for substance $P$ receptor subtypes. Embo J 1986, 5:2805-2808.

8. Okamura H, Yamamura T, Wakabayashi Y: Kisspeptin as a master player in the central control of reproduction in mammals: an overview of kisspeptin research in domestic animals. Anim Sci J 2013, 84:369-381.

9. Savio JD, Boland MP, Hynes N, Roche JF: Resumption of follicular activity in the early post-partum period of dairy cows. J Reprod Fertil 1990, 88:569-579.

10. Wakabayashi $Y$, Ohkura S, Homma T, Sakamoto K, Murata K, Mori Y, Maeda K, Okamura H: Effects of senktide, a neurokinin B receptor agonist, on neural activity of arcuate kisspeptin neurons and luteinizing hormone secretion in the goat [abstract]. In Program of the 40th Society for Neuroscience Annual Meeting: 13-17 Nov 2010. San Diego: USA: 2010:S594.4.

11. Tanaka T, Fujiwara K, Kim S, Kamomae H, Kaneda Y: Ovarian and hormonal responses to a progesterone-releasing controlled internal drug releasing treatment in dietary-restricted goats. Anim Reprod SCi 2004, 84:135-146.

12. Maeda K, Ohkura S, Uenoyama $Y$, Wakabayashi $Y$, Oka $Y$, Tsukamura $H$, Okamura H: Neurobiological mechanisms underlying $\mathrm{GnRH}$ pulse generation by the hypothalamus. Brain Res 2010, 1364:103-115.

13. Lehman MN, Coolen LM, Goodman RL: Minireview: kisspeptin/neurokinin B/dynorphin (KNDy) cells of the arcuate nucleus: a central node in the control of gonadotropin-releasing hormone secretion. Endocrinology 2010, 151:3479-3489.

14. de Croft S, Boehm U, Herbison AE: Neurokinin B activates arcuate kisspeptin neurons through multiple tachykinin receptors in the male mouse. Endocrinology 2013, 154:2750-2760.

15. Imakawa K, Day ML, Garcia-Winder M, Zalesky DD, Kittok RJ, Schanbacher $\mathrm{BD}$, Kinder JE: Endocrine changes during restoration of estrous cycles following induction of anestrus by restricted nutrient intake in beef heifers. J Anim Sci 1986, 63:565-571. 
16. Tanaka $T$, Yamaguchi $T$, Kamomae $H$, Kaneda $Y$ : Nutritionally induced body weight loss and ovarian quiescence in Shiba goats. J Reprod Dev 2003, 49:113-119.

17. Orita J, Tanaka T, Kamomae H, Kaneda Y: Ultrasonographic observation of follicular and luteal dynamics during the estrous cycle in Shiba goats. J Reprod Dev 2000, 46:31-37.

doi:10.1186/1756-0500-7-773

Cite this article as: Endo and Tanaka: Effects of senktide, a neurokinin 3 receptor agonist, on luteinizing hormone secretion and follicular development in anestrous Shiba goats: a pilot study. BMC Research Notes 2014 7:773.

\section{Submit your next manuscript to BioMed Central and take full advantage of:}

- Convenient online submission

- Thorough peer review

- No space constraints or color figure charges

- Immediate publication on acceptance

- Inclusion in PubMed, CAS, Scopus and Google Scholar

- Research which is freely available for redistribution 